Dhaka Univ. J. Biol. Sci. 26(1): 101-110, 2017 (January)

\title{
MYCOFLORA ASSOCIATED WITH INFECTED FRUITS OF DIFFERENT VARIETIES OF MUSA SAPIENTUM L. AND THEIR PATHOGENIC POTENTIALITY
}

\author{
Md Al-AmEen, S SHAMSI AND MA BASHAR* \\ Department of Botany, University of Dhaka, Dhaka-1000, Bangladesh
}

Key words: Mycoflora, Infected fruits, Musa sapientum, Pathogenic potentiality

\begin{abstract}
A total of 11 fungal species were isolated from the 25 infected fruit samples of three varieties (Sabri, Champa and Sagor) of Musa sapientum. The isolated fungi were Aspergillus flavus Link, A. fumigatus Fresenius, A. niger van Tiegh., Colletotrichum musae (Berk. \& Curt.) Arx, Curvularia brachyspora Boedijn., Fusarium semitectum Berk. \& Rav. Fusarium sp. Link, Penicillium sp., Pestalotiopsis disseminata (Thum) Steyaert, Rhizopus sp. Ehrenb. and Trichoderma viride Pers. ex Gray. Fusarium semitectum showed the highest (28.61) per cent association frequency in Sabri variety whereas Fusarium sp. showed the lowest (3.33). Curoularia brachyspora showed the highest (21.11) per cent frequency in Champa variety whereas A. fumigatus showed the lowest (2.78). Fusarium sp. showed the highest (41.67) per cent frequency in Sagor variety whereas T. viride showed the lowest (3.34). Among the isolated fungi C. musae, C. brachyspora, F. semitectum, Fusarium sp. and $P$. disseminata were found to be pathogenic to three banana varieties. The presence of Pestalotiopsis disseminata (Thum) Steyaert in Sabri variety of banana is the first record in Bangladesh.
\end{abstract}

\section{Introduction}

Banana (Musa sapientum L.) is the best-known tropical fruit and belongs to Musaceae $^{(1)}$. It is a nutritious fruit crop in the world and grown in many tropical areas where they are used both as a staple food and dietary supplements ${ }^{(2)}$. It is the fifth largest agricultural crop in world trade after cereals, sugar, cocoa and coffee. According to a report, the world production of banana was about 95 million tons and most of the production was consumed locally(3). It is one of the cheapest and economically important fruit crops grown in Bangladesh in both homestead and commercial farms. Bangladesh ranks 14th among the top 20 banana producing countries in the world. There are a number of banana cultivars in Bangladesh of which BARI Kola-1, Amritsagar, Sabri, Champa, Kabri and Sagor are commercially important. Like all other commercially important plants, one of the major bottlenecks of banana production is its constant exposure to different biotic and abiotic stresses. Fungal diseases play an important role

*Author for correspondence: <botanybashar@yahoo.com>. 
for the severe yield loss of banana. Major fungal diseases of banana are anthracnose (Colletotrichum musae), brown blotch (Pestalotiopsis leprogena), crown rot (Colletotrichum musae, Curvularia disseminata, Fusarium semitectum), fruit speckle (Fusarium semitectum), fruit rot (Pestalotiopsis disseminata), panama disease or Fusarium wilt (Fusarium oxysporum f. sp. cubense), etc. Anthracnose, crown rot and fruit rot are very common diseases in Narsingdi district. In Bangladesh, research on fungal diseases of banana fruits is very limited ${ }^{(4,5)}$. So, for the sake of economy more information are needed on this regard. Considering the importance of this popular fruit the present investigation was undertaken to record the association of fungi in different banana varieties of Bangladesh.

\section{Materials and Methods}

Three varieties of Musa sapientum viz., Sabri, Champa and Sagar Kola were selected for the experiment. Twenty five samples were collected and examined from three different Upazila, namely Shibpur, Belabo and Polash of Narsingdi district during May, 2015 to April, 2016. Samples were collected in separate sterile polyethylene bags, labeled properly and then brought to the laboratory for isolation of fungi. The fungi associated with banana were isolated following "Tissue planting method" on PDA medium according to Islam and Shamsi(6). One hundred inocula, each measuring $2 \mathrm{~mm}^{2}$ long were cut with a pair of sterilized scissors from the diseased fruit parts of the banana and kept in a sterile Petri plate. The inocula were washed with sterile water and then surface sterilized by dipping in 10\% Clorox solution for three minutes. The inocula were again washed with sterile water for three times. Finally, the inocula were placed inside the folds of a sterile blotting paper to remove the excess surface water. A total of 60 inocula were placed in 20 sterilized Petri plates containing PDA medium. Each Petri plate contained $15 \mathrm{ml}$ of PDA medium with an addition of 1 drop (ca. $0.003 \mathrm{ml}$ ) of lactic acid and incubated at $25 \pm 2^{\circ} \mathrm{C}$ for 7 days.

The microscopic structural characters of the isolated fungi were recorded under a digital camera. Morphological structures of the fungi were drawn in detail by the aid of camera lucida. Identities of the isolates were determined following the standard literatures ${ }^{(7-12)}$.

Pathogenicity test of the fungal isolates has been done following "detached fruit inoculation technique"(13). Healthy banana were collected from the selected market and sterilized with 10\% Chlorox. The sterilized bananas were placed into the germ-free desiccators for drying. Three holes were made on the sterilized surface of fruits with a sharp cork borer ( $5 \mathrm{~mm}$ diameter) at a depth of $4 \mathrm{~mm}$. For preparing inocula, $5 \mathrm{~mm}$ agar disc cut from the margin of actively growing culture of the test fungi. The prepared fungal mycelial agar disc was inoculated by sterilized inoculation loop in each $5 \mathrm{~mm}$ hole on the healthy banana surface. Three replications were maintained in each test pathogens. In control set, fresh PDA agar disc was used instead of fungal mycelial agar 
disc on the sterilized banana surface. Then both the control and the treated sets of banana were kept in separate sterilized plastic boxes. Characteristic symptoms of fruit rot appeared on inoculated fruits after 5 - 7 days of incubation at $25 \pm 2^{\circ} \mathrm{C}$. The fungi were isolated from artificially inoculated fruits and compared with naturally infected fruits.

\section{Results and Discussion}

A total of 11 fungi were isolated from the fruits of three infected varieties of Musa sapientum. The isolated fungi were Aspergillus flavus, A. fumigatus, A. niger, Colletotrichum musae, Curvularia brachyspora, Fusarium semitectum, Fusarium sp., Penicillium sp., Pestalotiopsis disseminata, Rhizopus sp. and Trichoderma viride (Tables 1 - 3).

Table 1. Per cent association frequency of fungi associated with infected Sabri kola collected from Shibpur Upazila, Narsingdi.

\begin{tabular}{lccccc}
\hline \multirow{2}{*}{$\begin{array}{l}\text { Name of } \\
\text { fungi }\end{array}$} & \multicolumn{3}{c}{ \% frequency of fungi at different intervals } & \multirow{2}{*}{ Mean } \\
\cline { 2 - 5 } & 05.08 .15 & 16.08 .15 & 11.10 .15 & 21.10 .15 & \\
\hline Aspergillus flavus & 13.33 & 6.67 & 27.78 & 13.33 & 15.28 \\
A. fumigatus & 13.33 & - & 11.11 & 6.67 & 7.78 \\
A. niger & 20.00 & - & 11.11 & 13.33 & 11.11 \\
Curvularia brachyspora & 13.33 & 40.00 & - & - & 13.33 \\
Fusarium semitectum & 26.67 & 13.33 & 27.78 & 46.67 & 28.61 \\
Fusarium sp. & - & - & - & 13.33 & 3.33 \\
Penicillium sp. & 6.67 & 20.00 & - & 6.67 & 8.33 \\
Pestalotiopsis disseminata & 6.67 & 20.00 & 22.22 & - & 12.22 \\
\hline
\end{tabular}

'-' = No fungal growth.

Table 1 shows that eight fungal species were isolated from the infected Sabri variety. The per cent frequency of $F$. semitectum was highest (28.61) which was followed by $A$. flavus (15.28), C. brachyspora (13.33), P. disseminata (12.22), A. niger (11.11), Penicillium sp. (8.33), A. fumigatus (7.78) and Fusarium sp. (3.33).

Nine fungal species were recorded from the infected Champa variety. The per cent frequency of $C$. brachyspora was highest (21.11) which was followed by Rhizopus sp. (17.22), A. flavus (12.78), Penicillium sp. (11.67), Fusarium sp. (10), A. niger (8.89), F. semitectum and T. viride (7.78) and A. fumigatus (2.78) (Table 2).

Seven fungal species were isolated from the infected Sagor variety. The highest per cent frequency was observed in Fusarium sp. (41.67) which was followed by C. musae (25), Penicillium sp. (11.67), A. flavus and Rhizopus sp. (6.67), A. fumigatus (5) and Trichoderma viride (3.34) (Table 3). 
Table 2. Per cent frequency of fungi associated with infected Champa Kola collected from Belabo upazila, Narsingdi.

\begin{tabular}{llllll}
\hline \multirow{2}{*}{$\begin{array}{l}\text { Name of } \\
\text { fungi }\end{array}$} & \multicolumn{3}{c}{ \% frequency of fungi at different intervals } & \multirow{2}{*}{ Mean } \\
\cline { 2 - 5 } & 17.08 .15 & 08.11 .15 & 20.11 .15 & 27.11 .15 & \\
\hline Aspergillus flavus & - & 40.00 & - & 11.11 & 12.78 \\
A. fumigatus & - & - & - & 11.11 & 2.78 \\
A. niger & 13.33 & - & - & 22.22 & 8.89 \\
Curvularia brachyspora & 53.33 & 20.00 & - & 11.11 & 21.11 \\
Fusarium semitectum & 20.00 & - & - & 11.11 & 7.78 \\
Fusarium sp. & - & - & 40.00 & - & 10.00 \\
Penicillium sp. & 6.67 & 20.00 & 20.00 & - & 11.67 \\
Rhizopus sp. & - & 20.00 & 26.67 & 22.22 & 17.22 \\
Trichoderma viride & 6.67 & - & 13.33 & 11.11 & 7.78 \\
\hline
\end{tabular}

'-' =No fungal growth.

Table 3. Per cent frequency of fungi associated with infected Sagar Kola collected from Polash upazila, Narsingdi.

\begin{tabular}{lccccc}
\hline \multirow{2}{*}{$\begin{array}{l}\text { Name of } \\
\text { fungi }\end{array}$} & \multicolumn{4}{c}{$\%$ frequency of fungi at different intervals } & Mean \\
\cline { 2 - 5 } & 15.09 .15 & 08.10 .15 & 30.11 .15 & 06.12 .15 & \\
\hline Aspergillus flavus & 13.33 & 6.67 & - & 6.67 & 6.67 \\
A. fumigatus & 13.33 & - & - & 6.67 & 5.00 \\
Colletotrichum musae & 46.67 & 53.33 & - & - & 25.00 \\
Fusarium sp. & - & 40.00 & 53.33 & 73.33 & 41.67 \\
Penicillium sp. & 20.00 & - & 13.33 & 13.33 & 11.67 \\
Rhizopus sp. & - & - & 26.67 & - & 6.67 \\
Trichoderma viride & 6.67 & - & 6.67 & - & 3.34 \\
\hline
\end{tabular}

'-' = No fungal growth.

Taxonomic descriptions of pathogenic fungi associated with three infected varieties of Musa sapientum.

1. Colletotrichum musae (Berk. \& Curt.) Arx, Verh. Akad. Wet. Amst. 51: 107 (1957).

(Fig. 1A)

Colonies often with abundant white aerial mycelium becoming grey with age, with abundant orchreous to cinnamon conidial masses, usually coalescing. Sclerotia absent. Setae absent. Conidia straight, cylindrical, obtuse at apices, $12-17 \times 4.5-5.5 \mu \mathrm{m}$. Appressoria common, medium to dark brown, irregular in shape, often with large or deep lobes, 9 - $13 \times 9$ - $11.5 \mu \mathrm{m}$, often becoming complex. 
Specimen examined: Isolated from diseased fruits of Musa sapientun, Belabo and Polash upazila, Narsingdi district, MA Ameen 01, Nov - Dec. 2015.

2. Curvularia brachyspora Boedijn.

(Fig. 1B)

Colonies effuse grayish black. Conidiophores septate, mostly unbranched, brown, solitary, straight or slightly undulating, up to $97.2 \mu \mathrm{m}$ long, $4.8-5.6 \mu \mathrm{m}$ thick. Conidia olivaceous brown, mostly three septate, mostly straight or slightly curved, third cell from the base is broader and darker than others, smooth, 20 - 26 into10 - $14 \mu \mathrm{m}$.

Specimen examined: Isolated from diseased fruits of Musa sapientun, Belabo, Shibpur and Polash upazila, Narsingdi district, MA Ameen 02, July - Dec. 2015.

3. Fusarium semitectum Berk. \& Rav. In Berkeley, Gravillea 3: 98, 1875.

(Fig. 1C)

Cultures at first white peach tinge and peach couloured from below. Aerial mycelium floccose, peach gradually changing to avellaneous and finally becoming buff brown (14 - 21 days). Sporodochia absent, brown stromatic pustules occasionally developed. Red, blue or violet pigmentation not observed.

Macroconidia formed in aerial mycelium from loosely branched conidiophores. Each branch terminates in a conidiogenous cell $19-24 \times 2-4 \mu \mathrm{m}$ which appears to form a conidium from a single apical pore and then to form successively a second, third or even fourth pore thus forming a polyblastic sympodial cell. The conidia vary from 3 to 5 septate and are curved with a wedge-shaped but not pedicellate basal cell and pointed apex. They measure: 3 septate $17-28 \times 2.5-4 \mu \mathrm{m}$ and 5 septate $22-40 \times 3.7-4 \mu \mathrm{m}$.

In older cultures especially after mass transfers a greater variation of conidial shape and size occurs, many 1 septate pyriform to obovate conidia, 10-12 $\times 2.5-3.5 \mu \mathrm{m}$, being formed.

Chlamydospores, often sparse, are globose, intercalary, 5 - $10 \mu$ diameter formed singly or in chains.

Specimen examined: Isolated from diseased fruits of Musa sapientun, Belabo, Shibpur and Polash upazila, Narsingdi district, MA Ameen 03, July - Dec. 2015.

\section{Fusarium sp. Link}

(Fig. 1D)

Colony initially pink colored and brownish white from below. Growth of colony was fluffy and reached $2-3 \mathrm{~cm}$ from below the Petri plate within 5 days. Microconidia and macroconidia were found. Aerial mycelium floccose, macroconidia formed in aerial mycelium from loosely branched conidiophores. Each branch terminates in a conidiogenous cell which appears to form a conidium from a single apical pore. The conidia vary from 2 to 3 septate and are not curved with nearly straight-shaped. 

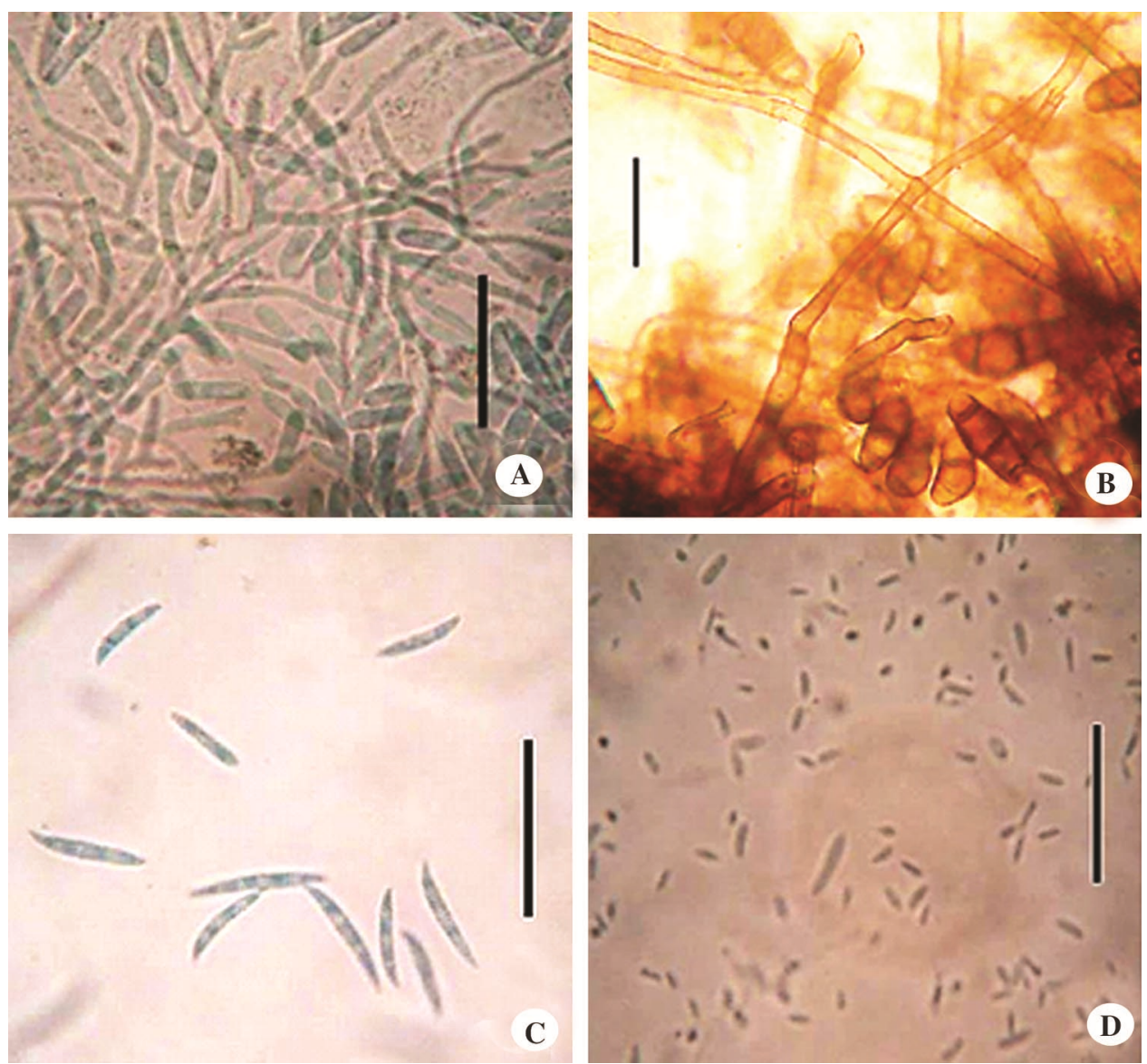

Fig. 1. Conidiophores and conidia of Colletotrichum musae (A) and Curvularia brachyspora (B), conidia of Fusarium semitectum (C) and Fusarium sp. (D) $($ Bar $=50 \mu \mathrm{m})$.

Macroconidiophores were simple, lateral, subulate phialides formed on the aerial hyphae; they may form short lateral branches. Macroconidia were formed under optimum growing conditions and these can readily be observed in situ under the low power of the microscope.

Microconidia formation was very common. The conidiophores may consist of a single basal cell bearing 2 - 3 apical phialides or it may form 2 - 3 metulae which in turn bear simple to obclavate phialides. Microconidia were thin-walled, with an elongated, often sharply curved apical cell and pedicellate basal cell. They are 1 septate. Chlamydospores were absent both in mycelium and conidia.

Specimen examined: Isolated from diseased fruits of Musa sapientun, Belabo, Shibpur and Polash upazila, Narsingdi district, MA Ameen 04, June - Dec. 2015. 
5. Pestalotiopsis disseminata (Thum) Steyaert

(Fig. 2)

Colonies white, cottony, reverse white. Hyphae septate, branched, hyaline. Acervuli becoming black and granular. Conidia end cells hyaline, intermediate three cells pale brown, apical setulae up to $20 \mu \mathrm{m}$ long, basal appendages 5 - $10 \mu \mathrm{m}$ long. Conidia $24-28$ $\times 7-8 \mu \mathrm{m}$.

Specimen examined: Isolated from healthy and diseased fruits of Musa sapientun, Belabo, Shibpur and Polash upazila, Narsingdi district, MA Ameen 05, July - Dec. 2015.
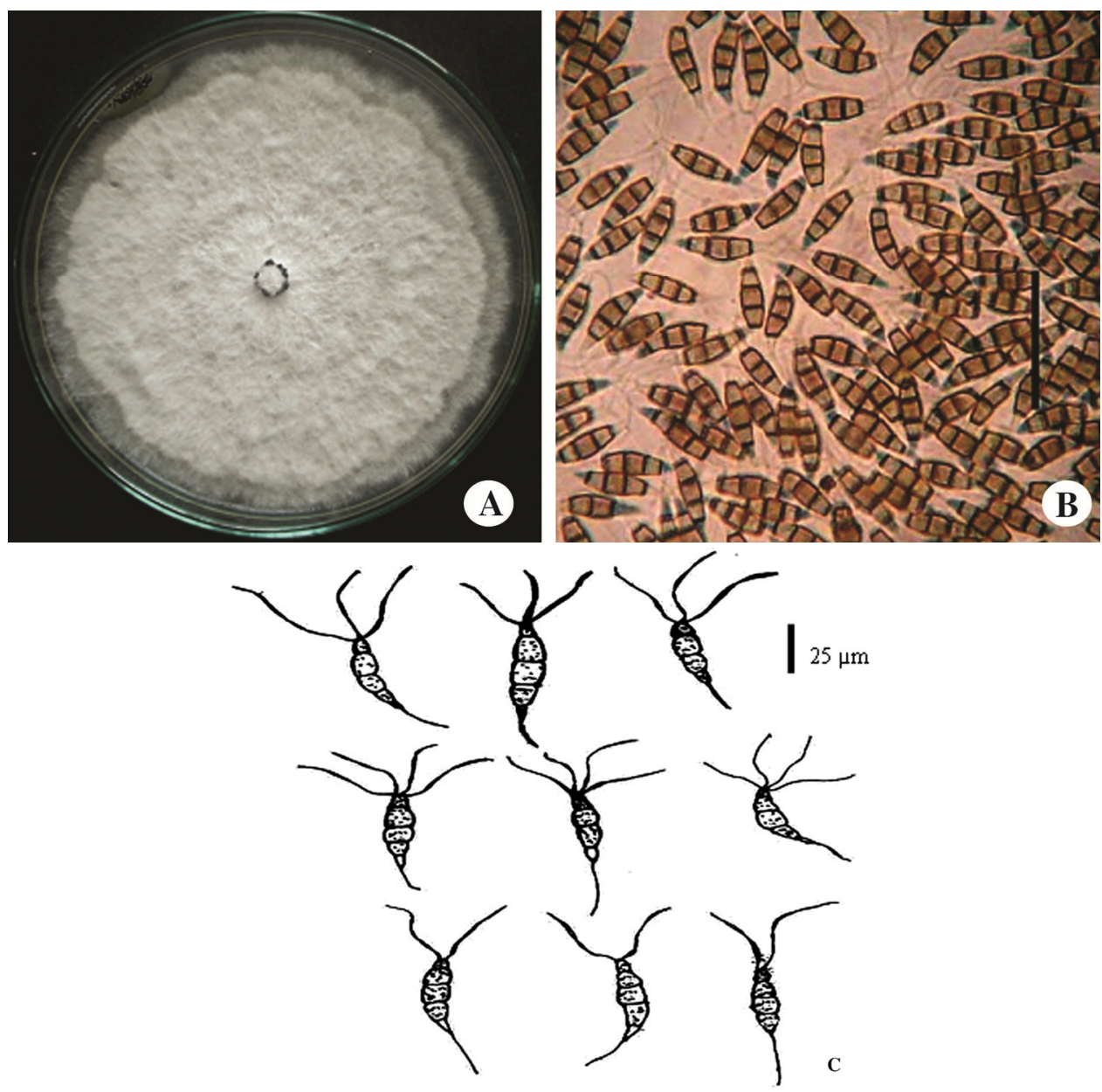

Fig. 2. Colony (A), conidia (B) and camera lucida drawing of conidia (C) of Pestalotiopsis disseminata $(\mathrm{Bar}=50 \mu \mathrm{m})$.

The fungi isolated from three infected banana varieties were tested for their pathogenic potentiality following detached fruit technique. Among the isolated fungi $C$. musae, C. brachyspora, F. semitectum, Fusarium sp. and P. disseminata were found to be 
pathogenic to all the tested banana varieties. Control set remains fresh without showing any fungal growth (Fig. 3).
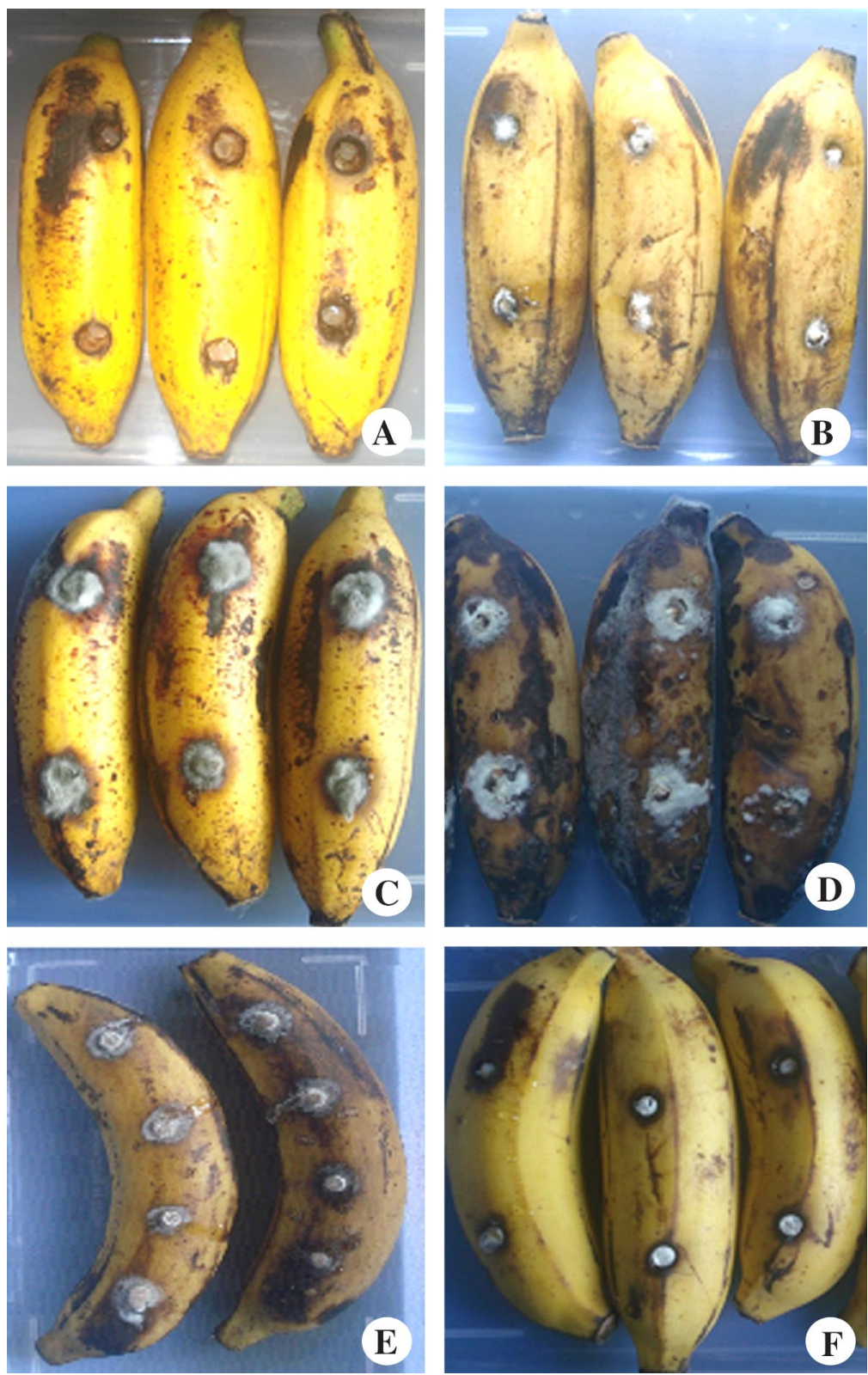

Fig. 3. Pathogenicity test of banana fruits of different varieties. Control (A), inoculated fruits with Colletotrichum musae (B), Curvularia brachyspora (C), Fusarium semitectum (D), Fusarium sp. (E) and Pestalotiopsis disseminata (F). 
Alvindia et al.(14) and Hirata et al.(15) reported Lasiodiplodia theobromae (Pat.) Griff. \& Maubl., Colletotrichum musae (Berk. \& Curt.) Arx, Thielaviopsis paradoxa (De Seynes) Höhn. Fusarium spp., as well as other fungi, associated with post-harvest diseases of banana. Nelson et al.(16) reported Acremonium, Colletotrichum musae, Curvularia, Fusarium and Verticillium from the crown rot diseases of banana. Odebode and Sanusi ${ }^{(17)}$ stated that Botryodiplodia theobromae was a major organism causing spoilage of banana in south-west part of Nigeria. They described that B. theobromae, Rhizopus oryzae, Aspergillus niger, A. flavus and Fusarium equrii were found to be associated with the ripening of banana and also caused rot during storage.

The findings of the present investigation slightly differed from others. Present results reveal that out of 11 fungal species five were pathogenic to the three varieties of Musa sapientum. The presence of Pestalotiopsis disseminata is the first record in Sabri Kola from Bangladesh.

\section{References}

1. Siddiqui KU, MA Islam, ZU Ahmed, ZNT Begum, MA Hassan, M Khondker, MM Rahman, SMH Kabir, M Ahmad, ATA Ahmed, AKA Rahman and EU Haque (eds.) 2007. Encyclopedia of Flora and Fauna of Bangladesh. Vol. 11. Angiosperm: Monocotyledons (Agavaceae-Najadaceae). Bangladesh Asiat. Soc. Dhaka, pp.399.

2. Assani AR, GHaicour, F Wenzel, F Cote, F Bakry, B Foroughiwehr, G Ducreux, ME Aguillarand AGrapin2001. Plant regeneration from protoplasts of dessert banana $\mathrm{cv}$. Grande Naine (Musa spp., Cavendish sub-group AAA) via somatic embryogenesis. Plant Cell Reports 20: 482-488.

3. Ganapathi TR, P Suprasanna, VM Kulkarni, VA Bapat and PS Rao 2002. Strategies for in vitro propagation and synthetic seeds in banana. BARC Newsletter (Founder's Day Special Issue): $\mathbf{1 6 8 .}$

4. Bashar MA, S Shamsi and M Hossain 2012. Fungi associated with rotten fruits in Dhaka Metropolis. Bangladesh J. Bot. 41(1): 115-117.

5. Anonymous 2005. Effect of plant extracts and bio-control agents against anthracnose disease of banana. M. Sc Thesis. Plant Pathology and Mycology Laboratory, Department of Botany, University of Rajshahi, Bangladesh. pp. 137.

6. Islam AA and S Shamsi 2016. Eco friendly management of mycoflora associated with Trichosanthes anguina L. and Trichosanthe dioica Roxb. I. J. R. S. B. 4(1): 52-56.

7. Gilman JC 1967. A Manual of Soil Fungi. Oxford and IBH Publishing Co., New Delhi, 2nd edn. (Revised). pp. $\mathrm{x}+450$.

8. Booth C 1971. The Genus Fusarium. Commonwealth Mycological Institute, Kew, Surrey, England. pp. 237.

9. Ellis MB 1971. Dematiaceous Hyphomycetes. The Commonwealth Mycological Institute, England. pp. 608.

10. Barnett HL and BB Hunter 1972. Illustrated Genera of Imperfect Fungi. Burgess Pub. Co., USA. pp. III +241 . 
11. Sutton BC 1980. The Coelomycetes. Fungi Imperfecti with Pycnidia, Acervuli and Stromata. Commonwealth Mycological Institute, England. pp. 696.

12. Ellis MB and JP Ellis1997. Micro Fungi on Land Plants. An identification Handbook. The Commonwealth Mycological Institute, England. pp. 868.

13. Shamsi S, N Naher and S Momtaz 2010. First report of Lasiodiplodia pod rots disease of cacao(Theobromae cacao. L.) from Bangladesh. Bangladesh J. Plant Pl. 26(1\&2): 81-82.

14. Alvindia DG, T Kobayashi, Y Yaguchi and KT Natsuaki 2000. Symptoms and the associated fungi of post harvest diseases on non-chemical bananas imported from the Philippines. Japanese Journal of Tropical Agriculture 44: 87-93.

15. Hirata T, E Kimishima, T Aoki, HI Nirenberg and K O'Donnell 2001. Morphological and molecular characterization of Fusarium verticillioides from rotten banana imported into Japan. Mycoscience 42: 155-166.

16. Nelson SC, R Ploetz and A Kepler 2006. Musa species (banana and plantain). Permanent Agriculture Resources, Hōlualoa, Hawai'i.

17. Odebode AC and J Sanusi 1996. Influence of fungi associated with bananas on nutritional content during storage. Zeitschriftfur Lebensmittel Untersuchung und Forchung 202(6): 471-473.

(Manuscript received on 8 December, 2016; revised on 29 January, 2017) 